\title{
More Dubious Dead Sea Scrolls
}

\section{Four Pre-2002 Fragments in the Schøyen Collection}

\author{
Årstein Justnes \\ University of Agder, Kristiansand, Norway \\ arstein.justnes@uia.no \\ Josephine Munch Rasmussen \\ University of Agder, Kristiansand, Norway \\ josephine.m.rasmussen@uia.no
}

\begin{abstract}
In the course of the last eighteen years more than 75 new "Dead Sea Scrolls" fragments have surfaced on the antiquities market. These are commonly referred to as post-2002 Dead Sea Scrolls-like fragments. A growing number of scholars regard a substantial part of them as forgeries. In this article, we will discuss four more dubious fragments, but this time from the 2oth Century-or at least from pre-2002. Two of the fragments have been known since the late nineties and are published in the DJD series. One was published in Revue de Qumran (2003), and one in Gleanings from the Caves (2016). All four are today accepted as part of the Dead Sea Scrolls dataset even though they are unprovenanced and have made-up — or at least very adaptable-lists of previous owners. In this article, we will critically review their provenance and discuss the lack of proper interest in provenance on the part of the collector who owns them and the scholars who published them.
\end{abstract}

\section{Keywords}

Dead Sea Scrolls-like fragments - unprovenanced objects - looted antiquities forgeries - antiquities trade - the Schøyen collection - critical provenance research Dead Sea Scrolls historiography 
In their 2019 article "Provenance vs. Authenticity: An Archaeological Perspective on the Post-2002 'Dead Sea Scrolls-Like' Fragments," Dennis Mizzi and Jodi Magness discuss the post-2002 fragments scandal from an archaeological perspective. ${ }^{1}$ They argue that the main issue with the post-2002 fragments is not the question of whether they are authentic or not, but that they are undocumented:

\begin{abstract}
Although much of the controversy surrounding the "Dead Sea Scrollslike" fragments that have surfaced since 2002 has focused on whether or not they are forgeries, the question of provenance is actually more fundamental and therefore of greater importance ... it is evident that the recent publication of these fragments is deeply problematic. Not only do most of them lack a known archaeological context, but their history of acquisition and ownership remains sketchy, to say the least. ${ }^{2}$
\end{abstract}

This problem is, however, far from confined to the post-20o2 fragments. In a 2017 paper presented at the Society of Biblical Literature's annual meeting in Boston, Årstein Justnes argued that some of the "Dead Sea Scrolls" manuscripts published in Discoveries in the Judaean Desert-especially those that surfaced in the nineties-have many of the same problems and traits as the forged Dead Sea Scrolls-like fragments that have flooded the market since $2002:^{3}$ They are undocumented, unprovenanced, and have a dubious, and sometimes fabricated, ownership history. ${ }^{4}$ Especially through the three so-called Miscel-

1 Mizzi and Magness, "Provenance vs. Authenticity." The authors say that the "article adds an archaeological voice to the current debate surrounding the authenticity of recently acquired 'Dead Sea Scrolls-like' fragments" (p. 135). For the record, it should be noted that this is not the first contribution from archaeologists on these fragments. One of the main promoters of the post-2002 fragments, Hanan Eshel, was himself an archaeologist. Eshel published extensively on these fragments. See the following contributions, listed in chronological order: Esther Eshel and Hanan Eshel, "A New Fragment of the Book of the Watchers"; "New Fragments from Qumran"; Hanan Eshel, Baruchi, and Porat, "Fragments of a Leviticus Scroll"; Esther Eshel, and Hanan Eshel, "Preliminary Report"; Hanan Eshel, Esther Eshel, and Broshi, "A New Fragment of XJudges"; Hanan Eshel, "Gleaning of Scrolls from the Judean Desert."

2 Mizzi and Magness, "Provenance vs. Authenticity," 146.

3 Justnes with Langslet, "Yet Another Fake?" This point is in fact indirectly illustrated by Mizzi and Magness' article. They seem to think that MS 2713, MS 2861, MS 4611, and MS 4612/1 are post-2002 fragments even though all four fragments surfaced before 2002. See below.

4 Furthermore, some of them were launched and published by the same scholars that eagerly marketed some of the post-2002 fragments. See Justnes, "Fake Fragments, Flexible Provenances." 
lanea volumes in Discoveries in the Judaean Desert (DJD 28, 36, and 38) —all from 2000 and 2001 - several artefacts of uncertain origin became part of the dataset. 5

In the present article, we revisit four fragments that became known between 1998 and 2001 and interpret them, not primarily as historical objects of unknown origin, but as modern and contemporary additions to the Dead Sea Scrolls historiography. We will critically review their provenance and discuss the lack of a proper interest in this issue on the part of the collector who owns them and the scholars who published them. ${ }^{6}$

Post-1998 or Post-2oo2 Dead Sea Scrolls-like Fragments?

In the last four years, we have seen a growing consensus among Dead Sea Scrolls scholars that the majority of the post-2002 Dead Sea Scrolls-like fragments are most likely modern forgeries. Since 2002, more than 75 new Dead Sea Scroll fragments have surfaced on the antiquities market. In 2013, The Dead Sea Scrolls Foundation introduced a new Brill series on its website mainly devoted to publishing 8 o new fragments that have "been sold or put up for sale" since 1998. ${ }^{7}$ Moreover, between November 2016 and April 2017, the number of new fragments was changed from 80 to $150 .{ }^{8}$

It is noteworthy that Weston W. Fields and the Dead Sea Scrolls Foundation use 1998 as the starting point of this story—and not 2002 as we have grown used to. ${ }^{9}$ Interestingly, too, James H. Charlesworth, Director and Editor of the

5 Cf. for instance Tov, Indices, 3: "In addition, the texts uncovered by some Israeli archeological missions are included in $D J D$..., as well as Kh.Q Ostraca $2-\mathbf{3}$ and a few texts of unknown provenance which surfaced in the second half of the 1990 os (XQ5a, $5 \mathbf{b}, 6-7$ [vol. XXXvi]; X1 [XXXVIII]; X2-6 [XXVIII])."

6 We are very grateful for the comments, corrections, and suggestions made by the two anonymous reviewers and the editor, Molly Zahn.

7 Dead Sea Scrolls Foundation, "How can you take part in the publication of the scrolls?" deadseascrollsfoundation.com, March 2013, https://web.archive.org/web/20130329091301/ http://www.deadseascrollsfoundation.com.

8 Dead Sea Scrolls Foundation, "How can you take part in the publication of the scrolls?" deadseascrollsfoundation.com, https://www.deadseascrollsfoundation.com/\#howto.

9 Fields, Review of Doyen of the Dead Sea Scrolls: "Milik was also important in ways quite apart from his Cave 4 work. For example, he played a critical role in the secret identification and preliminary transcription of the approximately 100-175 fragments (depending on how one counts) that were not part of the assignment of the Cave 4 team, but have been sold or offered for sale by the Kando family since 1998 and are identified by the Kando family as coming from Cave 4. Milik was not the only member of the Cave 4 team to have participated in this 
Princeton Theological Seminary Dead Sea Scrolls Project, operates with the late nineties as a major orientation point: In an interview in Biblical Archaeology Review in 2007, celebrating the Scrolls' 6oth anniversary, he made the following remark:

As long as 10 years ago I knew of more than 35 Dead Sea Scrolls that are still in private hands, purchased decades earlier. I published two of them in Discoveries in the Judaean Desert and will soon announce the recovery of a fragment of Genesis. ${ }^{10}$

In this statement Charlesworth makes a disturbing connection between the fragments published in the DJD series and the infamous post-2002 Dead Sea Scrolls-like fragments.

In Gleanings from the Caves, a group of four fragments from the Schøyen Collection is singled out as "High Quality Scrolls from the Post-Herodian Period,"11 namely MS 4611 (Lev), MS 2713 (Josh), MS 2861 (Judg), and MS 4612/1 (Joel). ${ }^{12}$ The first three fragments are an established part of the Dead Sea Scrolls dataset: MS 2713 and MS 2861 were published by Charlesworth in DJD 38 (2000) and DJD 28 (2001) respectively, ${ }^{13}$ while MS 4611 was published by Émile Puech in 2003. ${ }^{14}$ Neither Charlesworth nor Puech shows any critical interest in the provenance of these fragments. In each of his editions, Charlesworth devotes only two (formulaic and identical) sentences to this issue:

This manuscript of Joshua, purchased in 1998, probably derives from Qumran cave 4. However, as this cannot be proved, it is designated XJoshua. ${ }^{15}$

recent (and ongoing) effort to obtain additional texts from the family of the antiquities dealer through whom most of the Dead Sea Scrolls came to light."

10 Charlesworth, "35 Scrolls Still in Private Hands," 62.

11 See Davis, "High Quality Scrolls," 129-38. Kipp Davis describes these fragments as palaeographically distinct ("they exhibit a high quality, ornamental late or post-Herodian script").

12 Davis, "High Quality Scrolls," 129.

13 Charlesworth, "XJoshua," 231-39, and "XJudges," 231-33.

14 Puech, "Lévitique," 311-13.

15 Charlesworth, "XJoshua," 231. 
This manuscript of Judges, purchased in 1999, probably derives from Qumran cave 1 or 4. However, as this cannot be proved, it is designated XJudges. ${ }^{16}$

There is an obvious tension inherent in these statements. While the Cave 1 and/or 4 indication links the fragments to Qumran, the designations XJoshua and XJudges communicate that the fragments are unprovenanced. In DJD 38 , MS 2713 is the sole fragment under the heading "F. Unknown Origin" (p. 229) while XJudges forms part of the section "Texts of Unknown Origin" in DJD 28. Puech, in his edition of MS 4611, provides only a tight-lipped statement about its provenance ("Les fragments publiés ici appartiennent à des collections privées en Europe") $)^{17}$ and silently enrolls the fragment among other Cave 4 manuscripts by naming it $4 \mathrm{QLev}^{\mathrm{i}}(4 \mathrm{Q} 26 \mathrm{c})$. However, in Emanuel Tov's authoritative Revised Lists of the Texts from the Judaean Desert from 2010 all three fragments are definitively driven out of the caves, so to speak, and listed under the heading "19. Unknown Provenance" - without the prefix Q (= Qumran) as part of their item number and name of composition: ${ }^{18}$

\section{Schøyen Ms-number Item no. Composition}

\begin{tabular}{lll}
\hline MS 2713 & X1 $_{1}$ & XJosh \\
MS 4611 & X4 $_{4}$ & XLev $^{\text {; }}$ also known as 4QLev \\
MS 2861 & X5 $^{\mathrm{i}}$ (olim X6) & XJudga , frag. (pub. as XJudg) \\
\hline
\end{tabular}

16 Charlesworth, "XJudges," 231.

17 Puech, "Lévitique," 311. See further Elgvin, "MS 4611. Mur/HevLev," 159 n. 2: "In the publication Puech stated that he had the owner's permission to publish the fragment. When asked about the matter in May 2007 he stated: 'I do not remember details. I have had so many photographs on my desk, and so many middlemen who have come to me with photographs since 1970. If I wrote that I had the owner's permission to publish, I surely had an oral permission, either from the owner or through the middleman who gave me the photograph. I do not recall if the owner was William Kando or another, or whether this photo was given to me by a middleman. I can neither say whether I got this photograph before or after 1995. Sometimes a photograph can be on my desk a long time before I get to study it and then possibly publish it. I never publish fragments without permission (as some people do with my Starcky material) but such permissions are always given orally."

18 Tov, Revised List, 110. 
The reason why MS $4612 / 1$ (Joel) never made it onto Tov's list, despite its having been known since 2001, is probably its delayed publication. The fragment was published by Torleif Elgvin in 2016.9 Elgvin shows no concern for the provenance of the fragment, but speculates about its provenience (see below). ${ }^{20}$ The following year, at the sBL Annual Meeting, Justnes argued that MS $4612 / 1$ in all probability is a modern forgery. ${ }^{21}$ If this is the case, it is the first published pre-2002 fake Dead Sea Scrolls-like fragment we know of.

\section{$3 \quad$ Inventing Provenance}

In his personal reflection in Gleanings from the Caves (2016), Martin Schøyen says that he bought the four fragments from the Kando family following a trip to Israel in 1993:

During a later visit in 1993 I had a long conversation with William and Edmond Kando, two of Kando's sons ... Since Kando had sold fragments to several tourists and collectors from Europe and the USA who visited his shop in the 195os and later, I suggested that they should check their father's files and contact some of the customers mentioned there, or those they still remembered. Since these customers now would be old, they or their descendants might perhaps not be interested in keeping their fragments any longer. Four fragments were found; two of them were passed on to Professor James $H$. Charlesworth for research and subsequent sale to me.

In a signed statement William Kando says the following about the provenance of these fragments: 'We hereby confirm that the Joshua (MS 2713) and Judges (MS 2861) fragments, from Qumran acquired through James H. Charlesworth and the Joel (MS 4612/1) and Leviticus (MS 4611) fragments, were acquired by my father from members of the Bedouins in 1952-1953. At that time the caves in Qumran were not numbered and many of the locations not known, but we believe that all these fragments (except Judges) came from the cave near Khirbet Qumran later known as Cave 4. We sold these fragments to our old customer of the Kando family

19 Elgvin, “Ms 4612/1. Ḥev(?)Joel (Joel 4.1-5)," 223-32.

20 Provenience usually refers to the actual find spot and archaeological context of a find. Provenance, on the other hand, covers an object's history of ownership, including its provenience.

21 Justnes with Langslet, "Yet Another Fake?" See also discussion in Elgvin and Langlois, "Looking Back," 128-3o. 
in Zurich in 1956.' William Kando later added that they did not know from which cave the Judges fragment came. The name of the collector is not revealed here, as the heirs of this collector still had more fragments. Later they actually offered me another fragment of this Judges scroll, which I did not acquire [emphasis ours].22

The quote raises a number of issues, one of them being whether Schøyen acquired two of the fragments via Charlesworth, as stated, or if they were passed on to Charlesworth as a part of the settlement between the seller and Schøyen. It is clear both from catalogues and from the Schøyen Collection website that the four fragments were not bought at the same time, but over a period of several years. Notably, the confirmation from William Kando, which obviously must have been written after the last fragment was bought, contains Ms-numbers from the Schøyen Collection catalogue(!). It seems that the testimony was written to accommodate a favourable provenance for the fragments after the fact of the acquisition.

According to the 15th edition of "The Schøyen Collection: Checklist of Manuscripts 1-2867," Schøyen bought MS 2713 in January 1999. ${ }^{23}$ It is listed as "MS 2713* The Joshua b Dead Sea Scroll." MS 2861 is called "the Judges Dead Sea Scroll" and was, again according to the catalogue, bought in July 1999. The provenance of each of the fragments is listed according to the same pattern:

TABLE 1 15th edition of “The Schøyen Collection: Checklist of Manuscripts 1-2867," 1999

MS 2713

The Joshua b Dead Sea Scroll

Bible: Joshua 1:7-12; 2:2-3
MS 2861

The Judges Dead Sea Scroll

Judges 4:4-6
1. Community of the Essenes, Qumran (mid 1st c. BC-68 AD);

2. Qumran Cave 4 (68-1952);

3. Unknown previous owners, acquired Jan. 1999. ${ }^{24}$
1. Community of the Essenes, Qumran (2nd half of 1 st c. BC-68AD);

2. Qumran Cave 4 (68-1952);

3. Unknown previous owners, acquired July $1999 .^{25}$

22 Schøyen, "Acquisition and Ownership History," 29.

23 Schøyen, "Checklist of Manuscripts," 15.

24 Schøyen, "Checklist of Manuscripts," 15.

25 Schøyen, "Checklist of Manuscripts," 15. 
The name "Joshua b Dead Sea Scroll" is surprising. As only two manuscripts of Joshua have been found at Qumran, it seems likely that it refers to 4QJosh ${ }^{\mathrm{b}}$. This in turn raises the question: Was MS 2713 offered for sale by Charlesworthand bought by Schøyen — as a fragment of $4 \mathrm{QJ} \mathrm{osh}^{\mathrm{b}}{ }^{26}{ }^{26} \mathrm{In}$ Charlesworth's edition in DJD 38 it is worth noticing that a considerable amount of space is devoted to connecting MS 2713 to $4 \mathrm{QJosh}$. The parts "Relation to 4 QJosh" (p. 235) and "Reconstruction of Cols. I-III in Comparison with 4 QJosh ${ }^{b "}$ (pp. 236-39) in fact make up around $50 \%$ of the whole edition. Taking into account that MS 2713 was sold to Schøyen only a year or two before DJD 38 was published, one may wonder if Charlesworth's article was originally written up as an edition of 4 QJosh ${ }^{\mathrm{b}}$.

From 2001 to 2004 the provenance information for both of these fragments changes three times on the Schøyen Collection's webpage. In what follows, we quote from the available captions on the internet archive WayBackMachine and mark the changes with a cursive font:

TABLE 2 Provenance information according to the Schøyen Collection webpage, January and February 2001

\section{MS 2713}

The Joshua Dead Sea Scroll

Bible: Joshua 1:7-12; 2:2-3

\section{MS 2861}

\section{The Judges Dead Sea Scroll Judges 4:5-6}

10 February 2001:27

1. Community of the Essenes, Qumran (late 1st c. $\mathrm{BC}-68 \mathrm{AD})$;

2. Qumran Cave 4? (68-1952);

3. Unknown previous owners.
10 January $2001:^{28}$

1. Community of the Essenes, Qumran (2nd half of 1 st c. BC-68AD);

2. Qumran Cave 4 (68-1952);

3. Unknown previous owners.

26 Schøyen, "Checklist of Manuscripts," 15. Cf. Schøyen, "Checklist of Manuscripts," 15: "Dr. James H. Charlesworth identified the text, and will publish the MS in the DJD series and in the Princeton Theological Seminary Dead Sea Scrolls Project."

27 https://web.archive.org/web/20010210094926/http://www.nb.no/baser/schoyen/4/4.1/411 .html\#2713.

28 https://web.archive.org/web/20o101102315oo/http://www.nb.no/baser/schoyen/5/5.9/ index.html\#2861. 
Compared with the provenance information in the 1999 catalogue, the caption from 10 February 2001 (MS 2713) has been modified in four places: The ' $b$ ' in the name is removed. The fragment is now called "The Joshua Dead Sea Scroll," and a question mark is inserted after "Qumran Cave 4." In other words, it is no longer listed as a part of $4 \mathrm{QJjoshua}$. Also, the date is modified from "mid ist $\mathrm{c}$. вС" to "late ist с. вс." Furthermore, the information about the acquisition date is removed. This last element is also the case for MS 2861. Otherwise there are no changes in the description of this fragment compared with the 1999 catalogue.

Captions from 16 December 2002 reveal another major change: "Unknown previous owners" in the third point is replaced by "Private collection, Switzerland (1952-1999)":

TABLE 3A Provenance information according to the Schøyen Collection webpage, December 2002

MS 2713

The Joshua Dead Sea Scroll

Bible:Joshua 1:7-12; 2:2-3
MS 2861

The Judges Dead Sea Scroll

Judges 4:5-6
16 December 2002:29

1. Community of the Essenes, Qumran (late 1st c. BC-68 AD);

2. Qumran Cave 4? (68-1952);

3. Private collection, Switzerland (1952-1999).
16 December 2002: $:^{30}$

1. Community of the Essenes, Qumran (2nd half of 1st c. BC-68AD)

2. Qumran Cave 4 (68-1952)

3. Private collection, Switzerland (1952-1999).

On the same date, the two other fragments mentioned above (MS 4611 and $4612 / 1)$ appear on the webpage for the first time, with an identical provenance:

29 https://web.archive.org/web/20021216192112/http://www.nb.no/baser/schoyen/4/4.1/411 .html.

30 https://web.archive.org/web/20o212161359o8/http://www.nb.no/baser/schoyen/5/5.9/ index.html \#2861. 
TABLE 3B Provenance information according to the Schøyen Collection webpage, December 2002

MS 4611

The Leviticus Dead Sea Scroll

Bible: Leviticus 26:3-9, 33-35

\section{MS 4612}

Bible: Joel 4:1-4
16 December 2002:31

1. Community of the Essenes, Qum$\operatorname{ran}(30 \mathrm{BC}-68 \mathrm{AD})$;

2. Qumran Cave 4 (68-1952);

3. Private collection, Switzerland (1952-2001).
16 December 2002:32

1. Community of the Essenes, Qumran (3о BC-68AD);

2. Qumran Cave 4 (68-1952);

3. Private collection, Switzerland (1952-2001).

A year and a half later, in June 2004, all the four provenance lists are recalibrated, so to speak; all the fragments are now given the same provenance. Khalil Iskander Shahin — or Kando-is finally written into the provenance narrative as a new point three and the date of the private collection is changed from 1952-1999 to 1956-1995 (see Table 4).

Wrapping up this part, it should be noted that, on the Schøyen Collection's webpage, all four fragments were originally listed as unprovenanced objects. MS 2713 and MS 2861 were acquired in 1999 from Charlesworth while Ms 4611 and MS 4612/1 seem to have been bought two years later, in 2001. Much latermaybe as late as in 2004-all four of them became Kando fragments.

The provenance information of MS 2713 and MS 2861 changes at least twice on Schøyen's website between 2001 and 2004, and according to the same pattern: They are originally listed as unprovenanced, but at some point late in 2002 they are attributed to an (anonymous) Swiss collection, from $195^{2}$ to 1999. In 2004, this time frame is conveniently adjusted to $1956-1995 \cdot{ }^{33}$ This makes

31 https://web.archive.org/web/20021216192112/http://www.nb.no/baser/schoyen/4/4.1/411 .html $\# 5611$.

32 https://web.archive.org/web/200212161359o8/http://www.nb.no/baser/schoyen/5/5.9/ index.html $\#_{4} 612$.

33 Notably, 1995 is the date of the Unidroit Convention on Stolen or Illegally Exported Cultural Property. Since legal regulations are not retroactive, dating of the acquisitions to a time before the convention may create a flavour of legality. However, even if taken at face value, such a backdating does not really solve the legal issues involved, since the specificity of national legal frameworks in countries of origin is still relevant. 
TABLE 4 Provenance information according to the Schøyen Collection webpage, June 2004

\begin{tabular}{|c|c|c|c|}
\hline MS 2713 & MS 2861 & MS 4611 & MS $4612 / 1$ \\
\hline 3 June $2004::^{34}$ & 3 June 2004: ${ }^{35}$ & 3 June $2004:{ }^{36}$ & 3 June $2004:{ }^{37}$ \\
\hline $\begin{array}{l}\text { 1. Community of the } \\
\text { Essenes, Qumran } \\
\text { (late } 1 \text { st c. BC-68 AD) }\end{array}$ & $\begin{array}{l}\text { 1. Community of the } \\
\text { Essenes, Qumran (2nd } \\
\text { half of 1st c. BC-68AD) }\end{array}$ & $\begin{array}{l}\text { 1. Community of the } \\
\text { Essenes, Qumran } \\
\text { (3о BC-68AD); }\end{array}$ & $\begin{array}{l}\text { 1. Community of the } \\
\text { Essenes, Qumran } \\
\text { (3о вС-68AD) }\end{array}$ \\
\hline $\begin{array}{l}\text { 2. Qumran Cave 4? (68- } \\
\left.195^{2}\right)\end{array}$ & $\begin{array}{l}\text { 2. Qumran Cave } 4 \text { (68- } \\
\left.195^{2}\right)\end{array}$ & $\begin{array}{l}\text { 2. Qumran Cave } 4(68- \\
\text { 1952); }\end{array}$ & $\begin{array}{l}\text { 2. Qumran Cave } 4(68- \\
\left.195^{2}\right)\end{array}$ \\
\hline $\begin{array}{l}\text { 3. Khalil Iskander } \\
\text { Shahin ("Kando"), } \\
\text { Bethlehem (1952-- } \\
\text { 1956) }\end{array}$ & $\begin{array}{l}\text { 3. Khalil Iskander } \\
\text { Shahin ("Kando"), } \\
\text { Bethlehem (1952- } \\
\text { 1956) }\end{array}$ & $\begin{array}{l}\text { 3. Khalil Iskander } \\
\text { Shahin ("Kando"), } \\
\text { Bethlehem (1952- } \\
\text { 1956); }\end{array}$ & $\begin{array}{l}\text { 3. Khalil Iskander } \\
\text { Shahin ("Kando"), } \\
\text { Bethlehem (1952- } \\
\text { 1956) }\end{array}$ \\
\hline $\begin{array}{l}\text { 4. Private collection, } \\
\text { Switzerland (1956- } \\
\text { 1995) }\end{array}$ & $\begin{array}{l}\text { 4. Private collection, } \\
\text { Switzerland (1956- } \\
\text { 1995) }\end{array}$ & $\begin{array}{l}\text { 4. Private collection, } \\
\text { Switzerland (1956- } \\
\text { 1995). }\end{array}$ & $\begin{array}{l}\text { 4. Private collection, } \\
\text { Switzerland (1956- } \\
\text { 1995) }\end{array}$ \\
\hline
\end{tabular}

room for the elder Kando, who is now listed as their first owner (from $195^{2}$ to 1956). ${ }^{38}$ The provenance of MS 4611 and MS $4612 / 1$ changes more or less according to the same template, but as they were acquired later than MS 2713 and MS 2861, their provenance only changes once. Up until mid 2004, the provenance information on the Schøyen Collection webpage does not chime with William Kando's statement quoted in Gleanings from the Caves. The listing of the previous owner as "unknown" is particularly striking in the light of this statement. For several years, Schøyen did not disclose that the objects came from Kando, and implicitly claimed to have no knowledge of whom they were bought from. Presumably, the Kando provenance becomes more attractive for Schøyen from 2004 onwards. In retrospect, the scandal about the post-2002 fragments has illustrated the significant monetary value of the Kando provenance for Dead Sea Scrolls.

34 https://web.archive.org/web/200406o3144530/http://www.nb.no/baser/schoyen/4/4.1/411 .html.

35 https://web.archive.org/web/20040603144628/http://www.nb.no/baser/schoyen/5/5.9/ index.html $\#_{2} 861$.

36 https://web.archive.org/web/200406o3144530/http://www.nb.no/baser/schoyen/4/4.1/411 .html\#5611.

37 https://web.archive.org/web/200406o3144628/http://www.nb.no/baser/schoyen/5/5.9/ index.html $\# 4612$.

38 Schøyen's lists of previous owners are easy to parody. "Anonymous Swiss Collector" is a well-known euphemism for dubious provenance in the antiquities trade. There is even a blog called Anonymous Swiss Collector, addressing issues of art crime, https://www .anonymousswisscollector.com/. 


\section{Between Historical Context and Market Interests: Constructing Provenience for Unprovenanced Manuscripts}

In his 2010 article, Hanan Eshel spoke of XJoshua, XJudges, and XLev as three scrolls of "unknown provenance." However, for Eshel "unprovenanced" seemed to mean some unspecified location in the Judaean desert (still) limited to "Qumran or the Bar Kokhba-era Refuge Caves." ${ }^{39}$ Also in Gleanings from the Caves several attempts were made to construct a provenience for the four fragments, mainly with backing from Ira Rabin's physical testing and Michael Langlois' palaeographical analyses. Tacitly assuming that the fragments must have come from the Judaean Desert, Elgvin suggested that they "were more probably found in Murabba'at or Nahal Hever than the Qumran caves." 40 This also affected the labels he gave three of the fragments: Mur/HevLev (MS 2713), Mur/HevJosh (MS 4611), and Hev(?)Joel (MS 4612/1).

Within the context of Gleanings from the Caves, it seems like Rabin's thorough material analysis first and foremost yielded a clear negative result with regard to provenience: the physical profiles of the four fragments were interpreted as incompatible with a Qumran origin. ${ }^{41}$ Correspondingly, Langlois' palaeographical analysis pointed in a similar direction: "The late date of these ... scrolls ... suggests a different place of discovery than Qumran."42 As argued by Mizzi and Magness, this way of establishing provenience is highly problematic. ${ }^{43}$ But there is also another aspect: While Eshel and Elgvin were first and foremost interested in reconstructing an operational historical context for the interpretation of the manuscripts (i.e. the Judaean desert, with the exception of Qumran), their suggested provenience does not seem to have aligned with the owner's interests in the objects: Despite the fact that nothing, at least according to Gleanings, links the fragments to Qumran, Schøyen is apparently not willing to let go of the Qumran provenience: All the fragments are still listed as coming from Cave 4 on the Schøyen Collection web-

39 Hanan Eshel, "Gleaning of Scrolls," 84.

40 Elgvin, "Texts and Artefacts," 51 n. 2.

41 Rabin, "Material Analysis." See also the summaries in Elgvin, "Texts and Artefacts," 54: "Most of the fragments in this volume do not exhibit mineral traces of water sources close to the Dead Sea (such as those at Ein Feshka). This strongly indicates that these fragments derive from scrolls manufactured outside the Dead Sea region. This is true for MS 4611 (Lev), XJudg, MS 5214/1 (Deut 6), MS 5214/2 (Deut 32), MS 5233/1 (2 Sam 22), MS 4612/9 (Jer), Ms 4612/1 (Joel), MS 5233/2 (Ps), MS 5441 (Ruth), and MS 4612/3 (EschatFrg ar)."

42 Elgvin, "Texts and Artefacts," 54 n. 15.

43 Mizzi and Magness, "Provenance vs. Authenticity." See esp. 153-57. 
site. From a collector's point of view, this is still the most attractive provenience and therefore preferable.

\section{5}

\section{Beyond Authenticity: Handling Loot}

Traditionally, many manuscript scholars have based their research on access to material with a rather weak and unsubstantiated pedigree, much of which has most probably surfaced as the result of clandestine and illegitimate removal from its place of origin. Some scholars have themselves suggested that some or all of the fragments under scrutiny in this article were looted from the archaeological context in the 1980s:

[I] t seems, that at least two of these scrolls (XJudg and XLev) were recently found in the caves of the Judean Desert. ${ }^{44}$

It cannot be excluded that MS 4611 (Lev), MS 2713 (Josh), MS 2811 [sic] (Judg) and Ms 4612/1 (Joel) come from a Bar-Kokhba cave looted in the 1980s (cf. Elgvin, Davis and Langlois, Gleanings from the Caves, 48, 16o, $185^{-86,193,225) \cdot 45}$

If the fragments are indeed looted, it implies that they are illegally procured, having been clandestinely removed, and subsequently smuggled. Artefacts appearing without a documented legal provenance are most likely either looted or fake-or both. The way that unprovenanced artefacts traditionally have been (and still are) treated in Qumran studies gives the impression that the fear of forgeries contaminating the datasets is far greater than the fear of potential criminal liability connected to the handling of stolen goods. ${ }^{46}$

In their article, Mizzi and Magness thoroughly lay out the various positions regarding requirements for due diligence in scholars' handling and publishing of unprovenanced manuscripts. They conclude that the "critical distinction" between the post-2002 fragments and the Dead Sea Scrolls is that the latter "does not violate 'the 1970 rule' or Israel's antiquities legislation." 47 Beyond the fact that the ownership of the "original" scrolls and the Qumran site is con-

44 Eshel, "Gleaning of Scrolls," 85.

45 Elgvin and Langlois, "Looking Back," 130.

46 For an unpacking of this point, see Justnes and Rasmussen, "Hazon Gabriel: A Display of Negligence."

Mizzi and Magness, "Provenance vs. Authenticity," 157. 
tested, ${ }^{48}$ the often applied UNESCO 1970 Convention ${ }^{49}$ as a "rule" or as a threshold year for objects to be considered licit is for many reasons not a particularly robust tool to avoid unlawful deals. In general, dealings in objects with a documented history of ownership predating 1970 may still fail to adhere to the national legislations that were already in place in most countries before the time of the convention..$^{50}$ Correspondingly, institutional codes of conduct do not automatically guarantee due diligence: If the goal is to establish paths for scholars and collectors to access ancient artefacts of questionable pedigree, then the actual impact of codes of conduct is questionable. Provenance issues should not be regarded as obstacles to circumvent in order to pursue traditional research agendas, but as a topic of research in their own right.

\section{New Fragments, Official Publication Series, and the Market}

In Schøyen's 15th edition of "The Schøyen Collection: Checklist of Manuscripts 1-2867" (1999) the close ties between the first interpreter of MS 2713 and MS 2861, the facilitator of their sales, the official editor, and the director of one of the two main publication series become evident. It is the same person:

Dr. James H. Charlesworth identified the text [i.e. as a fragment of 4QJosh ${ }^{\mathrm{b}}$ ], and will publish the MS in the DJD series and in the Princeton Theological Seminary Dead Sea Scrolls Project. ${ }^{51}$

Preliminary description based on information from Dr. James H. Charlesworth, who will publish the MS in the DJD series and in the Princeton Theological Seminary Dead Sea Scrolls Project. ${ }^{52}$

In other words, when Schøyen bought the fragments, he likely knew that they were going to be published in the two major series for Dead Sea Scrolls. Need-

48 Israel's ownership of the scrolls is contested by Jordan and the Palestinian Authority. In particular, the transfer of objects from the West Bank to the Israel Museum in West Jerusalem during and after the 1967 war is a potential violation of the 1954 Hague Convention for the Protection of Cultural Property in the Event of Armed Conflict and its First Protocol.

491970 is the year of the UNESCO 1970 Convention on the Means of Prohibiting and Preventing the Illicit Import, Export and Transport of Ownership of Cultural Property.

$5^{\circ} \quad$ For a discussion, see Brodie, "Provenance and Price."

$5^{1}$ Schøyen, "Checklist of Manuscripts," 15.

$5^{2}$ Schøyen, "Checklist of Manuscripts," 87. 
less to say, this probably had a favorable effect on the prices. Charlesworth seems to have played a triple role in this-as market actor, as DJD editor for the two fragments, and as editor of the Princeton Dead Sea Scrolls series. ${ }^{53}$

\section{Implications for Further Research}

The main body of material presumed to have come from the Qumran caves does not have a documented findspot. And right from the start, experts involved in the study of the manuscripts and fragments were more interested in the textual aspects of the Scrolls than in the contextual aspects of their materiality. Mizzi and Magness suggest that the general reason for inclusion of dubious fragments in the Dead Sea Scrolls datasets is a lack of interest in and knowledge of archaeological perspectives among textual scholars. While it is noteworthy that the attention to archaeological context often is missing from the textual interpretations in Qumran studies, despite the archaeological training of some of its proponents, the lack of integration of archaeological documentation is not in and of itself necessarily the reason for the widespread use of pseudo-provenance. It may in fact be a symptom of the prevailing research methodologies in Qumran studies. Scholars and institutions sourcing data for textual research from published, unprovenanced artefacts will contribute to the propagation of validity issues through their own subsequent research. The prospect of this means that, through forgery and dubious ownership, the field of research is easily manipulated for religious, political, and monetary purposes. Beyond instances of individual scholars' mixing of roles and interests, rigorous methodology concerns the field at large.

\section{Summary and Conclusion}

All the four fragments under scrutiny in this article are unprovenanced and highly problematic for a whole range of reasons:

- MS 2713 was probably sold as a fragment of $4 \mathrm{QJosh}$ and with a promise that it would soon be published as a Dead Sea Scroll fragment in DJD 38 and in the Princeton series. MS 2861 seems to have been sold with a similar provenience and promise.

53 After we submitted this article, an additional element has come up regarding these two fragments. According to the recent scientific report by Art Fraud Insights ("Final Report," 7), MS 2713 and MS 2861 "bear a striking resemblance to the [fake] мотв [= Museum of the Bible] fragments." 
- MS 2713, MS 2861, and MS 4611 were all linked to Cave 1 and/or 4 by their editors. However, as the fragments do not appear to have come out of a cave, but out of nowhere, it seems pertinent to ask: Did the Cave 1 and/or 4 provenience have something to do with the market value of these fragments?

- For MS 2713 and MS 2861, the provenance information on the Schøyen Collection's webpage and catalogues changes notoriously, and at least once for MS 4611 and MS 4612/1. While Schøyen throughout the years has consistently linked all these fragments to Qumran Cave 4, several contributions in Gleanings from the Caves imply that there is in fact nothing that ties these fragments to the Qumran caves.

- None of the editors critically discusses provenance in their editions of these fragments or conducts due diligence. Their indications of provenience are mainly based on palaeography and were guided by the faulty and unfortunate premise that all four fragments must have come from the Judaean desert.

We still do not know where any of these fragments come from. Thus, as objects of study, these and other unprovenanced artefacts (forged and/or looted) bear testimony not so much to ancient communities as to the endeavours of the academic communities who have engaged with them. The present research into the recent biographies of these four fragments also traces a particular trait in the historiography of the Dead Sea Scrolls: the inclusion of unprovenanced material for the benefit of individual collectors and scholars at the potential cost of the validity of the affected fields of research.

\section{Bibliography}

Art Fraud Insights. "Museum of the Bible Dead Sea Scroll Collection Scientific Research and Analysis: Final Report." November, 2019. https://d2f 7 x7uhr2xem7.cloudfront .net/sixteen_by_nine/MOTB-DSS-Report-FINAL-web.pdf

Bernstein, Moshe, et al., eds. Qumran Cave 4. XXVIII:Miscellanea, Part 2. DJD 28. Oxford: Clarendon, 2001.

Brodie, Neil. "Provenance and Price: Autoregulation of the Antiquities Market?" European Journal on Criminal Policy and Research 20.4 (2014): 427-44.

Charlesworth, James H. "1. XJoshua." Pages 231-39 in Miscellaneous Texts from the Judaean Desert. Edited by James H. Charlesworth et al. DJD 38. Oxford: Clarendon, 2000.

Charlesworth, James H. "6. XJudges." Pages 231-33 in Wadi Daliyeh II: The Samaria Papyri from Wadi Daliyeh and Qumran Cave 4.XXVIII:Miscellanea, Part 2. Edited by Douglas M. Gropp. DJD 28. Oxford: Clarendon, 2001. 
Charlesworth, James H. "35 Scrolls Still in Private Hands." BAR 33.5 (2007): 6o-63.

Charlesworth, James H., et al., eds. Miscellaneous Texts from the Judaean Desert. DJD 38. Oxford: Clarendon, 2000.

Davis, Kipp. "High Quality Scrolls from the Post-Herodian Period." Pages 129-38 in Gleanings from the Caves: Dead Sea Scrolls and Artefacts from the Schøyen Collection. Edited by Torleif Elgvin, with associate editors Kipp Davis and Michael Langlois. LSTS 71. London: Bloomsbury T\&T Clark, 2016.

Elgvin, Torleif. “MS 2713. Mur/HevJosh (Josh 1.9-12; 2.3-5)." Pages 185-92 in Gleanings from the Caves: Dead Sea Scrolls and Artefacts from the Schøyen Collection. Edited by Torleif Elgvin, with associate editors Kipp Davis, and Michael Langlois. LSTS 71. London: Bloomsbury T\&T Clark, 2016.

Elgvin, Torleif. "Ms 4611. Mur/HevLev (Lev 26.3-9, 33-37)." Pages 159-67 in Gleanings from the Caves: Dead Sea Scrolls and Artefacts from the Schøyen Collection. Edited by Torleif Elgvin, with associate editors Kipp Davis and Michael Langlois. LSTS 71. London: Bloomsbury T\&T Clark, 2016.

Elgvin, Torleif. “MS 4612/1. Hev(?)Joel (Joel 4.1-5)." Pages 223-32 in Gleanings from the Caves: Dead Sea Scrolls and Artefacts from the Schøyen Collection. Edited by Torleif Elgvin, with associate editors Kipp Davis and Michael Langlois. LSTS 71. London: Bloomsbury T\&T Clark, 2016.

Elgvin, Torleif. "Texts and Artefacts from the Judaean Desert in The Schøyen Collection: An Overview." Pages 51-6o in Gleanings from the Caves: Dead Sea Scrolls and Artefacts from the Schøyen Collection. Edited by Torleif Elgvin, with associate editors Kipp Davis and Michael Langlois. LSTS 71. London: Bloomsbury T\&T Clark, 2016.

Elgvin, Torleif, and Michael Langlois. "Looking Back: (More) Dead Sea Scrolls Forgeries in The Schøyen Collection." RevQ 113 (2019): 111-33.

Eshel, Esther, and Hanan Eshel. "A New Fragment of the Book of the Watchers from Qumran (XQpapEnoch)." Tarbiz 73 (2004): 171-79 [Hebrew]; V [English Abstract].

Eshel, Esther, Hanan Eshel, and Magen Broshi. "A New Fragment of XJudges." DSD 14: 354-57.

Eshel, Esther, and Hanan Eshel. "A Preliminary Report on Seven New Fragments from Qumran." Meghillot 5-6 (2007): 271-78.

Eshel, Esther, and Hanan Eshel. "New Fragments from Qumran: 4QGen , 4QIsa 8QGen, and XQpapEnoch." DSD 12 (2005): 134-57.

Eshel, Hanan. "Gleaning of Scrolls from the Judean Desert." Pages 49-87 in The Dead Sea Scrolls: Texts and Context. Edited by Charlotte Hempel. STDJ 9o. Leiden: Brill, 2010.

Eshel, Hanan, Yosi Baruchi, and Roi Porat. "Fragments of a Leviticus Scroll (ArugLev) Found in the Judean Desert in 2004." DSD 13 (2006): 55-6o.

Fields, Weston W. Review of Doyen of the Dead Sea Scrolls: An In-Depth Biography of 
Józef Tadeusz Milik (1922-2006), by Zdzislaw J. Kapera and Robert Feather. Bible History Daily, 10 April 2013. https://www.biblicalarchaeology.org/reviews/doyen-of-the -dead-sea-scrolls/

Justnes, Årstein. "Fake Fragments, Flexible Provenances: Eight Aramaic 'Dead Sea Scrolls' from the 21st Century." Pages $242-71$ in Vision, Narrative, and Wisdom in the Aramaic Texts from Qumran. Edited by Mette Bundvad and Kasper Siegismund. STDJ 131. Leiden: Brill, 2020. https://brill.com/view/book/edcoll/9789oo4413733/ BPoooo18.xml

Justnes, Årstein, with Anders Langslet. "Yet Another Fake? Joel 4:1-5 (Dss F.117; Hev[?]Joel)." Paper presented at the Annual Meeting of the Society of Biblical Literature. Boston, 19 November 2017.

Justnes, Årstein, and Josephine Munch Rasmussen. "Hazon Gabriel: A Display of Negligence." BASOR 384.1 (2020): 69-76.

Langlois, Michael. "Palaeographical Analysis of the Dead Sea Scrolls in The Schøyen Collection." Pages 79-128 in Gleanings from the Caves: Dead Sea Scrolls and Artefactsfrom the Schøyen Collection. Edited by Torleif Elgvin, with associate editors Kipp Davis and Michael Langlois. LSTS 71. London: Bloomsbury T\&T Clark, 2016.

Mizzi, Dennis, and Jodi Magness. "Provenance vs. Authenticity: An Archaeological Perspective on the Post-2002 'Dead Sea Scrolls-Like' Fragments.” DSD 26 (2019): 135-69. Pfann, Stephen J., et al., eds. Qumran Cave 4. XXVI: Cryptic Texts and Miscellanea, Part 1. DJD 36. Oxford: Clarendon, 2000.

Puech, Émile. "Un autre manuscrit du Lévitique." Revue de Qumran 21/2 (2003): 311-13.

Rabin, Ira. "Material Analysis of the Fragments." Pages 61-77 in Gleanings from the Caves: Dead Sea Scrolls and Artefacts from the Schøyen Collection. Edited by Torleif Elgvin, with associate editors Kipp Davis and Michael Langlois. LSTs 71. London: Bloomsbury T\&T Clark, 2016.

Schøyen, Martin. "Acquisition and Ownership History: A Personal Reflection." Pages 27-32 in Gleanings from the Caves: Dead Sea Scrolls and Artefacts in The Schøyen Collection. Edited by Torleif Elgvin, with Kipp Davis and Michael Langlois. LSTS 71. London: Bloomsbury T\&T Clark, 2016.

Schøyen, Martin. “The Schøyen Collection: Checklist of Manuscripts 1-2867: Compiled by Elizabeth Gano Sørenssen." 15th edition, 1999.

Tov, Emanuel, ed. The Texts from the Judaean Desert: Indices and An Introduction to the Discoveries in the Judaean Desert Series. DJD 39. Oxford: Clarendon, 2002.

Tov, Emanuel. Revised List of Texts from the Judaean Desert. Leiden: Brill, 2010. 